\title{
Decreased Neutrophil Beta Adrenergic Receptors in the Neonate
}

\author{
YEAI ROAN ${ }^{(22)}$ AND STANLEY P. GALANT \\ Department of Pediatrics, University of Utah, Salt Lake City, Utah and Department of Pediatrics, University of \\ California, Irvine Long Beach Memorial Hospital, Long Beach, California, USA
}

\begin{abstract}
Summary
Using cord blood neutrophils (PMN) the maturity of the beta adrenergic receptor has been assessed. $\left[{ }^{3} \mathrm{H}\right]$-Dihydroalprenolol binding was utilized to determine receptor number and affinity and isoproterenol-induced cyclic AMP generation to characterize receptor function. Data from six neonates and six adult controls revealed that neonatal PMN had significantly $(P<0.001)$ fewer receptor sites $(728 \pm 43$ receptors/cell) compared to the adult $(1302 \pm 68$ receptors $/$ cell $)$; however, the affinity constants $\left(K_{D}\right)$ were very similar $(0.78 \pm 0.14 \mathrm{nM}$ compared to $0.61 \pm 0.05 \mathrm{nM})$. Neonatal PMN also generated less isoproterenol-induced cyclic AMP than adult cells at all concentrations, reaching significance $(P<0.005)$ at $10^{-4}-10^{-6} \mathrm{M}$ isoproterenol concentrations. No difference in the isoproterenol concentrations stimulating $50 \%$ of the maximal cyclic AMP generation $\left(\mathrm{EC}_{50}\right)$ was found between the two populations.

These data indicate that the neonatal PMN has decreased beta adrenergic receptor sites. No evidence of a receptor-adenylate cyclase coupling defect was detected. These findings could reflect ontogenic differences between the neonate and adult PMN. The effect of increased catecholamine secretion during the stress of delivery resulting in 'down regulation' of the beta adrenergic receptor cannot presently be ruled out.
\end{abstract}

\section{Speculation}

The ontogenesis of the beta adrenergic receptor has been shown in several animal species. Our data suggest that human neonatal neutrophils may have an immature beta adrenergic system with reduced number of receptor sites resulting in decreased beta adrenergic-induced adenylate cyclase activation. This might explain impaired adrenergic responsiveness reported in the human neonate.

Beta adrenergic catecholamines act by binding to specific plasma membrane receptors of target cells, thereby activating adenylate cyclase and stimulating generation of adenosine $3^{\prime}, 5^{\prime}$ monophosphate (cyclic AMP). Alteration in the affinity or density of beta adrenergic receptors may, therefore, determine the tissue responsiveness to catecholamines.

Studies in neonatal animals have demonstrated that hemodynamic responses to beta-adrenergic agents are less than those of adults. For example, the vascular reactivity and inotropic cardiac effect of administered adrenergic agents is subnormal in neonatal animals $(14,19)$. The mechanism of these altered physiologic responses can be studied on a molecular level by correlation with membrane-associated adenylate cyclase activity and the number and affinity of beta adrenergic receptors. Utilizing these techniques age-dependent changes in adenylate cyclase activity have been described for amphibian erythrocytes (15), rat liver (1) and rat myocardium (9). More recently, direct correlation between myocardial physiologic responsiveness to adrenergic agents and membrane beta adrenergic receptor binding and function has been compared in neonatal and older dogs (14).
Although few definitive studies of adrenergic responsiveness exists for the human neonate, immaturity of the autonomic nervous system has been implicated in a variety of clinical conditions. The purpose of this study is to compare the status of the beta adrenergic receptor system in the neonate with the mature human subject. For this purpose we have utilized the neutrophil (PMN) because this cell type is reasonably homogenous. It is accessible in reasonably large numbers (approximately $1.5-2.0 \times 10^{8} / 60 \mathrm{ml}$ ) and has been well characterized for beta adrenergic binding and function $(7,20)$. In this study we describe the number and affinity of neutrophil beta adrenergic receptors using the ligand $\left[{ }^{3} \mathrm{H}\right]-$ dihydroalprenolol (DHA) and characterize receptor function by isoproterenol-induced cyclic AMP generation.

\section{MATERIALS AND METHODS}

Subjects. Newborn samples were obtained from the placental cord blood of infants delivered vaginally at term without perinatal complications. The control samples were taken from young healthy adults; none of the mothers or control adults received any sympathomimetic agents or other drugs known to affect beta adrenergic function prior to delivery or venipuncture.

Cell preparation. Neutrophils were prepared and assayed for cyclic AMP by the method of Davis et al. (4) Whole blood was collected in nonheparinized glass tubes containing a dextran (mol wt. 170,000, Sigma)-heparin (sodium, preservative-free, Sigma) mixture (5:1 proportions) and allowed to sediment for $25-30$ minutes at room temperature. The leukocyte-rich fraction was then underlayered with Ficoll-Hypaque and spun at $400 \times g$ for $30 \mathrm{~min}$ at $20^{\circ} \mathrm{C}(2)$. The resultant pellet washed 3 times with physiologic saline. The neutrophils in the pellet constituted $95 \%$ of the nucleated cells in this fraction. The \% PMN band forms as assessed by Wright stained smears was $12.0 \pm 2.25 \%$ ( \pm S.E.) for the neonate and $0.75 \pm 0.05 \%$ for adult controls.

Cyclic AMP assay. For the cyclic AMP assay $5 \times 10^{6}$ neutrophils/tube were preincubated for $5 \mathrm{~min}$ at room temperature in incubation buffer $(50 \mathrm{mM}$ Tris, $\mathrm{pH} 7.5$ and $8 \mathrm{mM}$ theophylline in physiologic saline) and then exposed to media alone or to hormone (isoproterenol) at $37^{\circ} \mathrm{C}$ in a total volume of $100 \mu \mathrm{l}$ for $5 \mathrm{~min}$. Accumulation of cyclic AMP was terminated by boiling for $5 \mathrm{~min}$ and freezing for at least $30 \mathrm{~min}$. The samples were thawed and assayed for cyclic AMP by saturation method of Brown et al. (3). This method permitted quantitative recovery of exogenous $\left[{ }^{3} \mathrm{H}\right]-$ cyclic AMP. The results are expressed as picomoles $/ 10^{6}$ cells.

DHA binding assay (6). The binding assay utilized the same incubation condition as for cyclic AMP. $\left[{ }^{3} \mathrm{H}\right]$-Dihydroalprenolol $(0.1-10 \mathrm{nM})$ was incubated with $5 \times 10^{6}$ neutrophils/tube containing in an incubation volume of $180 \mu \mathrm{l}$ of $1 \mathrm{mM}$ ascorbic acid, $0.1 \mathrm{mM}$ phentolamine and $0.3 \mathrm{mM}$ catechol (which are thought to block nonreceptor binding sites) for $15 \mathrm{~min}$ at $37^{\circ} \mathrm{C}$ and stopped with $5 \mathrm{ml}$ of Tris $\mathrm{HCl} 50 \mathrm{mM}$ and $10 \mathrm{mM} \mathrm{MgCl}_{2}$ for $30 \mathrm{sec}$. The mixture was then rapidly filtered through a Gelman A-E glass fiber filter presoaked with stop buffer containing $0.1 \mathrm{mM}$ DLpropranolol. The filters were rapidly washed with $25 \mathrm{ml}$ incubation buffer and counted in a liquid scintillation system. Specific bind- 
ing represents the total number of DHA counts minus DHA binding in the presence of $1.0 \mu \mathrm{M}$ DL-propranolol, and was 50$80 \%$ of the total amount bound at all DHA concentrations. All samples were run in duplicate and differed from each other by no more than $15 \%$. Specific binding was linear with the cell number used for these experiments.

Calculations. Statistical analysis utilized nonpaired Student's $t$ test.

Materials. Most reagents were obtained from sources previously listed (7). Components for the cyclic AMP assay were purchased from Amersham Corp., Arlington Hts., IL.

\section{RESULTS}

Beta adrenergic receptor binding. DHA binding experiments from six control adults and six newborn infants are shown in Figure 1. In both infant and adult groups DHA binding is saturable with "apparent" saturation occurring at $5.0 \mathrm{nM}$ DHA concentration. The infant group binds significantly $(P<0.05)$ less DHA at all ligand concentrations compared to the adult population. Scatchard plot analysis of the mean data for each group (inset Fig. 1) shows that DHA binds to a single class of high affinity sites on the neutrophil membrane. The mean \pm S.E. for $B$ max and $K_{D}$ was calculated from Scatchard analysis of all subjects. From these data the total number of receptors/neutrophil was determined (Table 1). The affinity of DHA binding to neonatal beta adrenergic receptors $\left(\mathrm{K}_{\mathrm{D}}, 0.78 \pm 0.14\right)$ is not statistically different $(P>0.10)$ from that of adult cells $\left(K_{\mathrm{D}}, 0.61 \pm 0.05\right)$. However, there are significantly fewer $(P<.001)$ total numbers of beta receptors on neonatal PMN $(728 \pm 43)$ compared to adult PMN (1302 \pm 68$)$.
Cyclic AMP responses. Figure 2 is a comparison of isoproterenol-induced cyclic AMP generation of five neonatal and five adult subjects' neutrophils expressed in terms of picomoles $/ 10^{6}$ cells. Neonatal cells generate significantly less $(P<0.005)$ cyclic AMP than adult cells at isoproterenol concentrations of $10^{-6}-10^{-4} \mathrm{M}$. No significant differences $(P>0.2)$ are seen for basal levels. Although considerably less cyclic AMP is genrated in neonatal cells at $10^{-7}-10^{-8} \mathrm{M}$ isoproterenol concentration, these do not reach statistical significance. From these data (Fig. 2) the concentration of isoproterenol stimulating 50\% maximal cyclic AMP generation $\left(\mathrm{EC}_{50}\right)$ was calculated and found to be nearly identical in neonatal $(0.9 \mu \mathrm{M})$ and adult $(1.1 \mu \mathrm{M})$ cells.

\section{DISCUSSION}

Our data show that the neonatal cord PMN has a marked decrease in beta adrenergic binding and function when compared to adult cells. Thus, neonatal cells have approximately $56 \%$ of the number of receptor sites found on adult PMN, but the binding affinities are similar. In conjunction with reduced receptors, the neonatal PMN generates only $44 \%$ of the cyclic AMP found in the adult case. Furthermore, the fact that the $\mathrm{EC}_{50}$ value for isoproterenol does not differ significantly between the two populations suggests no defect in receptor-adenylate cyclase coupling efficiency in neonatal cells.

These observations could reflect the status of beta adrenergic function in other tissues. Little is known about the ontogenesis of beta adrenergic receptors in man. Human placental is rich in several hormone receptor types including the beta adrenergic receptor (17). DHA binding capacity of the placenta appears to decrease with increasing gestational age (17). However, preterm

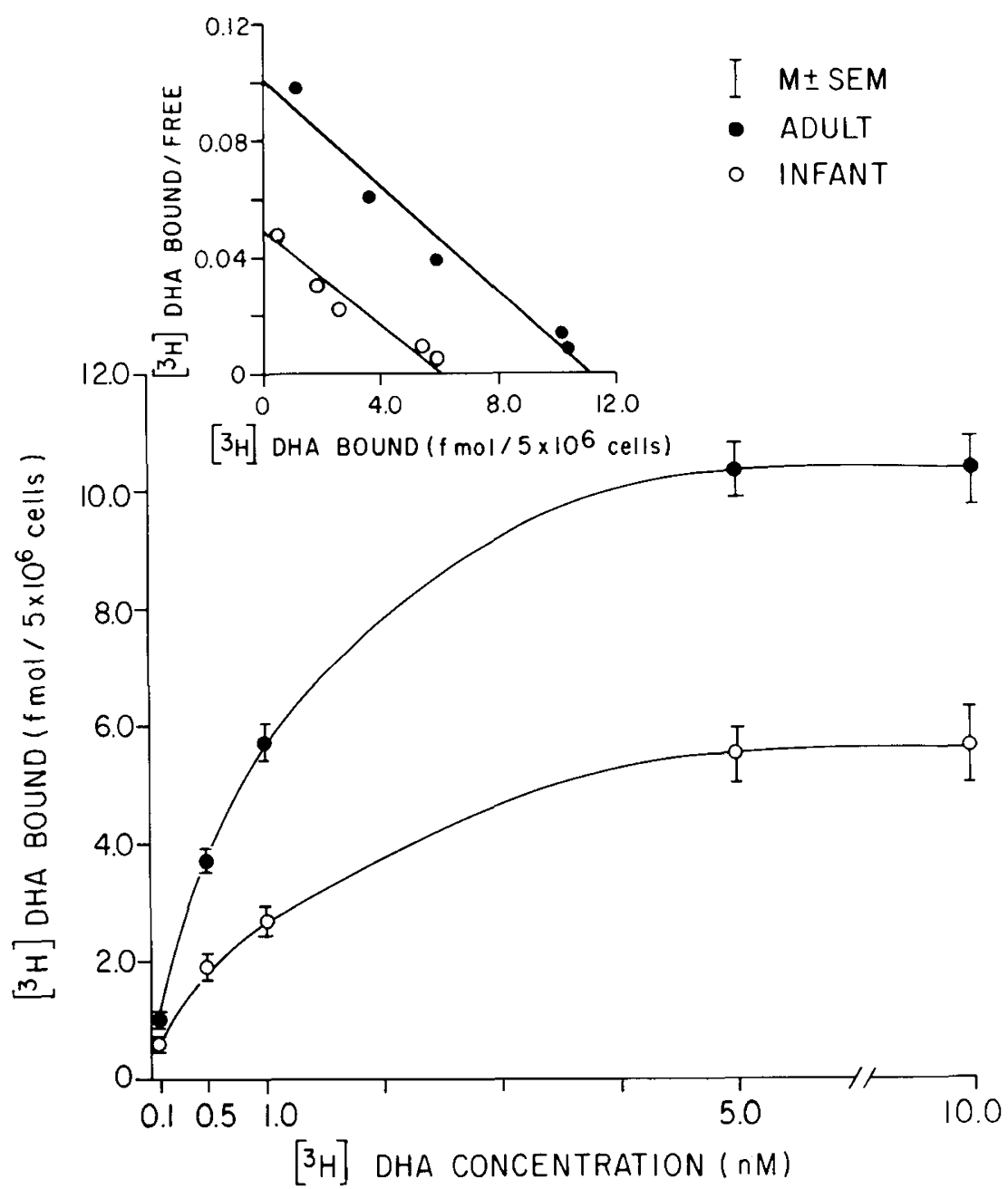

Fig. 1. $\left[{ }^{3} \mathrm{H}\right]$-Dihydroalprenolol (DHA) concentration curve for neutrophil beta adrenergic receptor binding: Shown is the mean \pm S.E. specific DHA binding for six infants and six adult subjects. In the inset is shown the least squares linear regression fit of Schatchard plot analysis of the mean data. 
Table 1. Results of $\left[{ }^{3} \mathrm{H}\right]$ DHA binding assay

\begin{tabular}{lcc}
\hline & Dissociation constant $\left(\mathrm{K}_{\mathrm{D}}\right) \mathrm{nM}$ & Receptor number \\
\hline Infant & $0.78 \pm 0.14^{1}$ & $728 \pm 43$ \\
Control & $0.61 \pm 0.05$ & $1302 \pm 68$ \\
$P$ Value $^{2}$ & N.S. & $<0.005$ \\
\hline
\end{tabular}

' Mean \pm S.E.

${ }^{2}$ Student $t$ test.

${ }^{3}$ Statistically not significant.

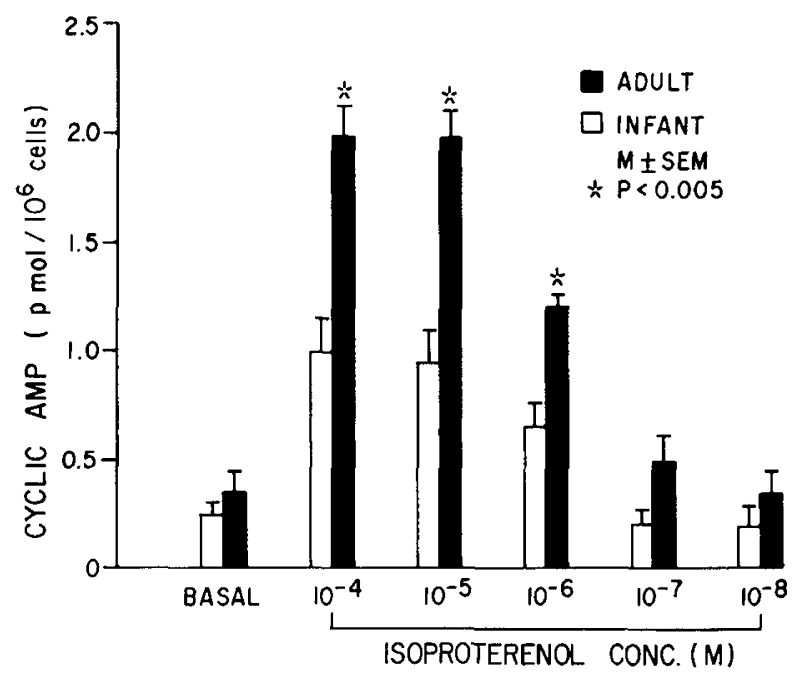

Fig. 2. Isoproterenol-induced neutrophil cyclic AMP stimulation in five infants and five adult subjects.

infants are not a homogenous population making interpretation of these data difficult. In several animal species increased beta adrenergic receptor sites are seen in lung, heart and placenta with increasing gestational age $(12,16,18)$. However, Rockman and co-workers (14) recently described an increased number of highly coupled beta adrenergic receptors in the myocardium of neonatal dogs compared to older dogs, inspite of markedly decreased physiologic responses to beta adrenergic drugs. This rather paradoxical finding was explained on the basis of a compensatory mechanism for depressed adrenergic responsiveness. In the case of the human neonate, decreased adrenergic responses if present, could be secondary to a decreased number of receptor sites. This would result in either decreased tissue sensitivity to adrenergic agents or a decrease in the maximum tissue responsiveness depending on receptor-coupling efficiency or presence of spare receptors.

Another important consideration is the effect decreased beta adrenergic receptor activity might have on neonatal PMN function since cyclic AMP has been shown to modulate PMN chemotaxis (13) and lysosomal enzyme release (20). Thus, diminished cyclic AMP generation could have a profound effect on the inflammatory response in the neonate.

It cannot be determined from the present study whether the decreased beta adrenergic receptor system in the neonate or receptor 'down regulation' secondary to increased circulation catecholamines known to be present in cord blood (5). The duration of elevated catecholamine in the fetus is unknown. Maternal catecholamine levels are normal during the third timester but are elevated during labor (10) which might raise fetal epinephrine levels for several $h$. In a previous study we showed that "down regulation' of neutrophil beta adrenergic receptors might require 3 days of beta adrenergic drug administration before profound decreases are seen (7). In addition, the stress of birth could result in increased plasma corticosteroid levels. Corticosteroids, however, are thought to increase beta adrenergic activity (11).

Two other considerations must be included in the interpretation of our data. First, the number of immature PMN was considerably greater in cord than in adult blood. Beta receptor binding and function in immature PMN have not been well characterized. Although we have previously shown no influence of the numbers of band forms on cyclic AMP generation (8) this difference in PMN maturity might have influenced our results. Second, we did not determine kinetic characteristics of cyclic AMP generation in neonatal PMN. However, since cyclic AMP generation in adult PMN peaks at 15-30 sec (unpublished observation), 5 min should have been adequate in both cell populations. Measurement of beta adrenergic binding and function at the end of the first wk of life will be required to resolve the issue of immaturity versus 'down regulation.' The PMN beta adrenergic receptor model may prove extremely useful in defining the ontogeny of the beta adrenergic system in man.

\section{REFERENCES AND NOTES}

1. Bar, H. H. and Hahn, P.: Development of rat liver adenyl cyclase. Can. J. Biochem., 49: 85 (1971).

2. Böyum, A.: Isolation of mononuclear cells and granulocytes from blood, II. Isolation of mononuclear cells by 1 centrifugation and of granulocytes by combining centrifugation and sedimentation of $1 \mathrm{~g}$. Scand. J. Clin. Invest., 21 : 77 (1968).

3. Brown, B. C., Albano, J. D. M., Ekins, R. P., and Sgherzi, A. H.: A simple and sensitive saturation assay for the measurement of adenosine $3: 5^{\prime}$ cyclic monophosphate. Biochem. J., 121: 561 (1971).

4. Davis, P. B., Braunstein, M. and Jay. C.: Decreased adenosine $3^{\prime}: 5^{\prime}$ monophosphate responses to isoproterenol in cystic fibrosis leukocytes. Pediatr. Res. 12: 703 (1978).

5. Eliot, R. J., Lam, R., Leake, R. D. I., Hobel, C. J. and Fisher, D. A.: Plasma catecholamine concentrations in infants at birth and during the first 48 hours of life. J. Pediat. 96: 311 (1980).

6. Galant, S. P. and Allred. S. J.: Binding and functional characteristics of beta adrenergic receptors in the intact neutrophil. J. Lab. Clin. Med., 98: 227 (1981).

7. Galant, S. P., Duriseti, L., Underwood, S. and Insel, P. A.: Decreased betaadrenergic receptors on polymorphonuclear leukocytes after adrenergic therapy. N. Engl. J. of Med., 299: 933 (1978).

8. Galant, S. P., Norton, L., Herbst, J. and Wood. C.: Impaired beta adrenergic receptor binding and function in cystic fibrosis neutrophils. J. Clin. Invest., 68: 253 (1981).

9. Kohrman, A. F.: Patterns of development of adenyl cyclase activity and norepinephrine responsiveness in the rat. Pediatr. Res., 7: 575 (1973).

10. Lederman, R. P., McCann, D. S. and Work Jr., B.: Endogenous plasma epinephrine and norepinephrine in last trimester pregnancy and labor. Am. J. Obstet. Gynecol., 129: 5 (1977).

11. Marone, G., Thomas, L. L., and Lichtenstein, L. M.: The role of agonists that activate adenylate cyclase in the control of CAMP metabolism and enzyme release by human polymorphonuclear leukocytes. J. Immunol., 125: 2277 (1980).

12. Moore, J. J. and Whitsett, J. A.: Ontogeny of B adrenergic receptor in rabbit placenta. Pediatr. Res. (Abstract) 15: 498 (1981).

13. Rivken, I., Rosenblatt, J., and Becker, E. L.: The role of cyclic AMP in the chemotactic responsiveness and spontaneous motility of rabbit peritoneal neutrophils. J. Immunol., I15: 1126 (1975).

14. Rockson, S. G., Homcy, C. J., Quinn, P., Manders, W. T., Haber, E. and Vatner, S. F.: Cellular mechanisms of impaired adrnergic responsiveness in neonatal dogs. J. Clin. Invest., 67: 319 (1981).

15. Rosen, O. M. and Erlichman, J.: The development of hormone sensitivity by adenyl cyclase of the tadpole erythrocyte. Arch. Biochem. Biophys., 133: 171 (1969).

16. Whitsett, J. A. and Darovec-Beckerman, C.: B adrenergic receptor and adenylate cyclase in developing rat myocardium. Pediatr. Res., (Abstract) 15: 475 (1981).

17. Whitsett, J. A., Johnson, C. L., Noguchi, A., Darovec-Beckerman, C. and Costello, M.: B adrenergic receptors and catecholamine-sensitive adenylate cyclase of the human placenta. J. Clin. Endocrinol. Metab.. 50: 27 (1980).

18. Whitsett, J. A., Needelman, $H$. and Pollinger, J.: Ontogeny and thyroid dependent maturation of $\mathrm{B}$-adrenergic receptors and adenylate cyclase in rat lung. Pediatr. Res., (Abstract) 15: 516 (1981).

19. Young, M. and Cottom, D.: Arterial and venous blood pressure responses during a reduction in blood volume and hypoxia and hypercapnia in infants during the first two days of life. Pediatrics, 37: 733 (1966).

20. Zurier, R. B., Weissman, G. and Hoffstein, S.: Mechanisms of lysosomal enzyme release from human leukocytes II. Effects of CAMP and CGMP, autonomic agonists an agents which affect microtubule function. J. Clin. Invest., 53: 297 (1974).

21. The current address of Dr. Y. Roan: Department of Pediatrics, University of Utah, Salt Lake City, UT 84132

22. Requests for reprints should be addressed to: Dr. Yeai Roan, Assistant Professor of Pediatrics, Department of Pediatrics, University of Utah Medical Center, 50 North Medical Dr., Salt Lake City, UT 84132.

23. Received for publication July 6, 1981.

24. Accepted for publication November 12, 1981. 